\title{
Clonal Evolution of Gastric Lymphoma of Mucosa- Associated Lymphoid Tissue Type
}

Amane Yamauchi, M.D., Yasuhiko Tomita, M.D., Hideaki Miwa, M.D., Haruhiko Sakamoto, M.D., Haruo Sugiyama, M.D., Katsuyuki Aozasa, M.D.

Second Department of Pathology (AY, HS), Kagawa Medical University, Kagawa, Japan; and Departments of Pathology (YT, HM, KA) and Clinical Laboratory Science (HS), Osaka University Medical School, Suita, Japan

Development of multiple lesions is frequent in gastric lymphoma of mucosa-associated lymphoid tissue (MALT) type. Presence of clonal components in multiple lesions was examined on the resected samples from 18 cases by using PCR-based method for immunoglobulin heavy-chain gene rearrangement. There were two or more lesions in 10 cases, and 2 to 12 samples were obtained from each lesion. The remaining eight cases had a single large lesion, from which two to six samples were collected from separate areas from each other. A total of 86 samples were analyzed. Histologic findings in each sample were categorized as follows: proliferation of exclusively centrocyte-like cells (CCL), large cells, and combined CCL and large cells. Monoclonal or biclonal pattern (single or two bands) was observed in 42 samples, oligoclonal pattern (three or more bands) in 30, polyclonal (smear) in 11, and no products in 3. Large-cell-type lesions showed fewer bands than those with other histologic types, and $75 \%$ of cases with large-cell type had mono- or biclonal proliferation. Common clones were found among lesions in about $60 \%$ of cases. Especially in 4 cases including 2 cases with large-cell type, every lesion in the same case contained the common clones. These findings suggested that gastric MALT lymphoma started as multi- or oligoclonal proliferation of cells, in which separate lesions composed of different clones from each other. As disease advances, dominant clones appear in some lesion and disseminate to other lesions via homing properties of the proliferating B lymphocytes.

Copyright (C) 2001 by The United States and Canadian Academy of Pathology, Inc.

VOL. 14, NO. 10, P. 957, 2001 Printed in the U.S.A.

Date of acceptance: June 27, 2001.

Supported in part by the Ministry of Education, Science and Culture of Japan (Grants 10042005, 10151225, 11470353, 11670212, 11680546, 12576004, 12670159, and 12770087).

Address reprint requests to: Katsuyuki Aozasa, M.D., Department of Pathology, Osaka University Medical School, 2-2 Yamadaoka, Suita, Osaka 565-0871, Japan; fax: 81-6-6879-3713.
KEY WORDS: Clonality, Gastric lymphoma, MALT, Multiple lesions, PCR

Mod Pathol 2001;14(10):957-962

Stomach is the commonest site for development of lymphoma of mucosa-associated lymphoid tissue (MALT) type $(1,2)$, which largely encompasses the condition previously called as reactive lymphoid hyperplasia (RLH). Gastric MALT lymphoma is histologically characterized by a proliferation of small lymphoid cells with irregularly shaped nuclei and abundant cytoplasm, i.e., centrocyte-like cells, and the presence of lymph follicles $(1,2)$, which might be formed in the preceding follicular gastritis caused by Helicobacter pylori infection (1-3). MALT lymphoma usually shows a slow clinical course, often localized in the stomach for several or $>10$ years, but can transform into large-cell lymphoma followed by progressive clinical course $(1,2)$.

Development of multiple lesions is frequent in gastric MALT lymphoma $(1,2,4)$. Isaacson et al. and Drillenburg et al. $(5,6)$ regarded these lesions to be derived from the same clone of cell, and explained the multiplicity based on the homing properties of the proliferating B lymphocytes. Several studies seemed to support this idea by showing the same clonal origin of metachronously developed multiple lesions $(7,8)$.

Assessment of clonality among the proliferating cells is a helpful method for diagnosis of malignancies including malignant lymphomas (9). For B-cell proliferation, rearrangement pattern of immunoglobulin heavy-chain gene was examined initially by the Southern blot method $(10,11)$. Subsequently, polymerase chain reaction (PCR)-based methods were established and widely used to detect clones of cell in lymphoproliferative lesions (12-16). When compared with Southern blotting, this method is a faster, relatively simple, and inexpensive technique that avoids the use of radioactive materials and a requires smaller amount of DNA. In 
addition, it is applicable to DNA extracted from formalin-fixed, paraffin embedded tissues.

In this study, presence of clonal components in multiple lesions of the same case or multiple points of the single but widely spreading lesion were examined on the resected samples of gastric lymphoma by using the PCR-based method for rearrangement of immunoglobulin heavy-chain gene.

\section{MATERIALS AND METHODS}

Through review of the surgical pathology files of the Osaka Police Hospital, Osaka Rosai Hospital, Sumitomo Hospital, Sakai Municipal Hospital, and Kaizuka Municipal Hospital, all situated in the Osaka district, Japan, 18 cases of gastric lymphomas were selected for the present study. Brief profiles of these patients are shown in Table 1. They were admitted to the hospitals during the period from 1990 to 2000 . The age of patients ranged from 45 to 80 (median 61) years, with male to female ratio of 12:6. All of these patients underwent gastrectomy. Macroscopically, lymphomatous lesions in each case were categorized into three groups: flat infiltrating lesion (flat type), bulky tumor on a flat infiltrating lesion (flat \& bulky type), and bulky tumor (bulky type). Histologic findings in each sample were divided into three groups: proliferation of exclusively centrocyte-like cells (CCL), large cells, and combined CCL and large cells (combined type; Table 1). In lesions exclusively containing CCL, there was almost monomorphous proliferation of CCL intermingling with a few centrocytes, centroblasts, and plasma cells. Reactive lymphoid follicles were occasionally found with infiltration of CCL in the germinal center, thus forming so-called follicular colonization. These findings were identical with those of MALT lymphoma of low-grade malignancy. Combined type usually consisted of $\geq 30 \%$ large cells. Multiple $(\geq 2)$ lesions were found in 10 cases, and 2 to 12 samples were obtained from each lesion. In the remaining eight cases, there was a single large, irregularly shaped lesion, from which at least two areas separate from each other were selected; two to six samples per case were analyzed.

Histologic specimens were fixed in $10 \%$ formalin and routinely processed for paraffin-embedding. Histologic sections cut at $4 \mu \mathrm{m}$ were stained with hematoxylin and eosin and immunoperoxidase procedures (abitin-biotin complex method). Primary antibodies used for immunophenotyping of lymphomatous lesions, their supplies and dilutions were as follows: Mx-Pan B (CD20; Kyowa Medix, Tokyo, Japan, 50×), MB-1 (Bioscience, Emmenbrucke, Switzerland, 50×), UCHL-1 (CD45RO) (Dakopatts, Glostrup, Denmark, 100×), and MT-1 (CD43; Bioscience, $50 \times$ ). All types of lymphomatous lesion were $\mathrm{CD} 20+$ and/or $\mathrm{MB}-1+, \mathrm{CD} 43-$, or $\mathrm{CD} 45 \mathrm{RO}-$, showing B-cell nature of the proliferating cells.

\section{DNA Extraction}

DNA was extracted from 87 formalin-fixed, paraffin-embedded samples $(17,18)$. Briefly, ten $5-\mu \mathrm{m}$ sections were cut from each sample and transferred into the microtubes, dewaxed in xylene for 15 minutes, rehydrated with absolute ethanol

TABLE 1. Brief Profiles and Patterns of Polyacrylamide Gel Electrophoresis in 18 Cases with Gastric Lymphoma

\begin{tabular}{|c|c|c|c|c|c|c|c|}
\hline \multirow{2}{*}{$\begin{array}{l}\text { Case } \\
\text { No. }\end{array}$} & \multirow{2}{*}{$\begin{array}{l}\text { Macroscopic } \\
\text { Type }\end{array}$} & \multirow{2}{*}{$\begin{array}{l}\text { No. of } \\
\text { Different } \\
\text { Lesions }\end{array}$} & \multirow{2}{*}{$\begin{array}{l}\text { Microscopic } \\
\text { Type }\end{array}$} & \multicolumn{3}{|c|}{$\begin{array}{c}\text { PAGE Patterns and Number of Samples in Each } \\
\text { Histologic Type }\end{array}$} & \multirow{2}{*}{$\begin{array}{c}\text { Presence } \\
\text { of } \\
\text { Common } \\
\text { Bands } \\
\text { (Samples) }\end{array}$} \\
\hline & & & & CCL & Combined & Large Cell & \\
\hline 1 & Flat & 1 & CCL & $\mathrm{M}(2)$ & & & Yes $(2)^{*}$ \\
\hline 2 & Flat & 1 & CCL & $\mathrm{O}(5)$ & & & Yes (5) \\
\hline 3 & Flat & 2 & CCL & $\mathrm{M}(1) \mathrm{P}(1)$ & & & No (2) \\
\hline 4 & Flat & 2 & CCL & $\mathrm{M}(1) \mathrm{O}(1) \mathrm{P}(1)$ & & & No (3) \\
\hline 5 & Flat & 1 & Combined & $\mathrm{M}(1) \mathrm{O}(4)$ & $\mathrm{O}(1)$ & & Yes (6) \\
\hline 6 & Flat & 1 & Combined & $\mathrm{O}(1)$ & $\mathrm{M}(1) \mathrm{P}(2)$ & & No (4) \\
\hline 7 & Flat & 1 & Combined & & $\mathrm{O}(5)$ & & Yes (5) \\
\hline 8 & Flat & 2 & Combined & $\mathrm{M}(1) \mathrm{O}(1)$ & $\mathrm{O}(1)$ & $\mathrm{O}(1)$ & Yes (4) \\
\hline 9 & Flat & 2 & Combined & $\mathrm{M}(1) \mathrm{O}(1)$ & $\mathrm{O}(1)$ & & Yes (3) \\
\hline 10 & Flat & 2 & Combined & $\mathrm{M}(3)$ & $\mathrm{P}(1)$ & & No (4) \\
\hline 11 & Flat & 3 & Combined & $\mathrm{O}(1) \mathrm{P}(1)$ & & $\mathrm{M}(1) \mathrm{O}(1) \mathrm{P}(1)$ & No (5) \\
\hline 12 & Flat & 8 & Combined & $\mathrm{O}(4)$ & $\mathrm{M}(1) \mathrm{O}(3) \mathrm{N}(1)$ & & Yes (9) \\
\hline 13 & Flat & 10 & Combined & $\mathrm{M}(1) \mathrm{O}(2) \mathrm{P}(4)$ & $\mathrm{O}(1)$ & & No (8) \\
\hline 14 & Flat and bulky & 3 & Combined & & $\mathrm{O}(4)$ & & Yes (4) \\
\hline 15 & Bulky & 2 & Combined & & $\mathrm{M}(2) \mathrm{O}(8) \mathrm{N}(2)$ & & No (12) \\
\hline 16 & Bulky & 1 & Combined & $\mathrm{O}(1)$ & $\mathrm{O}(1)$ & $\mathrm{M}(1)$ & Yes $(3)^{*}$ \\
\hline 17 & Bulky & 1 & Large cell & & & $\mathrm{M}(1) \mathrm{O}(2)$ & Yes $(3)^{*}$ \\
\hline 18 & Bulky & 1 & Large cell & & & $\mathrm{M}(3) \mathrm{O}(1)$ & Yes $(4)^{*}$ \\
\hline
\end{tabular}

${ }^{a}$ Presence of a common band among every sample.

PAGE, polyacrylamide gel electrophoresis; $\mathrm{M}$, monoclonal pattern (single band); O, oligoclonal pattern (two or more bands); P, polyclonal pattern (smear); N, no PCR products. 
for 5 minutes, suspended in digestion buffer $(50 \mathrm{~mm}$ TrisHCl, pH 8.5, 1 mM EDTA, and 0.5\% Tween20) containing $200 \mu \mathrm{g} / \mathrm{mL}$ proteinase $\mathrm{K}$ and was incubated at $56^{\circ} \mathrm{C}$ for 5 days with daily replacement of proteinase $\mathrm{K}(200 \mu \mathrm{g} / \mathrm{mL}$ of working concentration). Subsequently $30 \%(\mathrm{w} / \mathrm{v})$ Chelex-100 resin (BioRad) was added to each tube and boiled to inactivate Proteinase K. Supernatant was used as DNA template for PCR. The quality of the specimen DNA were assessed using a primer pair, KM29 and KM38, located in the human $\beta$-globin gene, which amplified a 262-bp length of fragment (17).

\section{PCR Protocol}

Ideally, FR3-JH PCR should be the choice for clonality analysis because it amplifies only the CDR3, the most diversified region of the Ig gene, and thus gives the best resolution. Therefore, at first, clonality analysis was performed with primer recognizing not only FR2 but also FR3 region; seminested PCR using FR3A and LJH for the first PCR and FR3A and VLJH for the second PCR, as described previously (13). But $>40 \%$ of samples showed smears in PAGE by this method. Failure to produce bands with FR3A primer was reported previously by Theriault et al. (16). They speculated that the failure to produce bands might be due to somatic mutations in MALT lymphoma. When FR2A primer was used, much better results were obtained, i.e., only approximately $15 \%$ of samples showed smears or no PCR products. Then, FR2A primer was used for the analysis. Seminested PCR was performed using primers FR2A and $\mathrm{LJH}$ for Round 1 and FR2A and VLJH for Round $2(14,15)$. Briefly, a total of $25-\mu \mathrm{L}$ solution containing PCR buffer II (Perkin-Elmer, Norwalk, CT), $0.5 \mu \mathrm{L}$ of template DNA, 25 pmol each of FR2A and LJH primers, $200 \mu \mathrm{mol} / \mathrm{L}$ of each dNTP, $1.5 \mathrm{~mm}$ of $\mathrm{MgCl}_{2}$, and $1.25 \mathrm{U}$ of $\mathrm{Taq}$ polymerase (Ampli Taq Gold, Perkin-Elmer) was used for Round 1 reaction. One $\mu \mathrm{L}$ of Round 1 product was diluted at 1:100 and used as the template for Round 2 PCR reaction with the same buffer as Round 1, containing VLJH but not $\mathrm{LJH}$ primer. Round 1 reaction included $95^{\circ} \mathrm{C}$ preheating for 10 minutes and 35 cycles of $95^{\circ} \mathrm{C}$ denaturation for 15 seconds, $62^{\circ} \mathrm{C}$ annealing for 30 seconds, and a $72^{\circ} \mathrm{C}$ extension for 1 minute. Round
2 included $95^{\circ} \mathrm{C}$ preheating for 10 minutes and 30 cycles of $95^{\circ} \mathrm{C}$ denaturation for 15 seconds, $65^{\circ} \mathrm{C}$ annealing for 30 seconds, and a $72^{\circ} \mathrm{C}$ extension for 1 minute. The Round 2 PCR products were denatured at $95^{\circ} \mathrm{C}$ for 5 minutes and then cooled at $4^{\circ} \mathrm{C}$ for 30 minutes to form homoduplex and heteroduplex $(19,20)$, electrophoresed in $5 \%$ polyacrylamide gels, stained with SYBR Gold Nucleic Acid Gel Stain (21) Molecular Probes, Eugene, OR), and finally analyzed with FM BIOII Multi View (Hitachi Software Engineering, Yokohama, Japan). Each amplification was duplicated.

DNA extracted from the Raji cell line was used as a positive control for clonal proliferation, and PCR mixture without DNA was used as a negative control. In addition, 10 cases of chronic tonsillitis were also examined.

\section{Sequence Analysis}

Definite bands on the polyacrylamide gels were cut under ultraviolet light and purified with the QIAquick Gel Extraction Kit (QIAGEN, Valencia, CA), labeled with ABI PRISM Big Dye Terminator Cycle Sequencing Ready Reaction Kit (PE Biosystems, CA), and analyzed with ABI PRISM 310 Genetic Analyzer (Perkin-Elmer).

\section{RESULTS}

One of 87 DNA samples did not give bands after PCR amplification of the $\beta$-globin gene and thus was excluded from the study. Remaining 86 samples were used for further analysis, and PCR products could be detected in 83 samples. Results of polyacrylamide gel electrophoresis (PAGE) are shown in Tables 1 and 2. The positive controls always showed monoclonal pattern, that is, single band. All of the chronic tonsillitis cases showed a smear. Negative controls always showed no products. Monoclonal (uni- or biallelic) or biclonal pattern was observed in 42 samples, oligoclonal pattern (three or more bands) in 30, and polyclonal (smear) in 11 (Figs. 1 to 4 ). There were no prominent differences in histologic features between lesions with monoclonal or biclonal, oligoclonal, and polyclonal pattern. Lesions with exclusive large

TABLE 2. Patterns of Polyacrylamide Gel Electrophoresis According to Histologic Type in Each Sample

\begin{tabular}{lcccccc}
\hline \multirow{2}{*}{ Histologic type } & \multicolumn{5}{c}{ Polyacrylamide Gel Electrophoresis Pattern } & N \\
\cline { 2 - 5 } & \multicolumn{1}{c}{$\mathrm{M}$} & $\mathrm{O}(2)$ & $\mathrm{O}(>2)$ & $\mathrm{P}$ & \\
\hline CCL & $11(28.2 \%)$ & $7(17.9 \%)$ & $14(35.9 \%)$ & $7(17.9 \%)$ & $0(0 \%)$ & $39(100 \%)$ \\
Combined & $4(11.4 \%)$ & $11(31.4 \%)$ & $14(40.0 \%)$ & $3(8.6 \%)$ & $3(8.6 \%)$ & $35(100 \%)$ \\
Large cell & $6(50.0 \%)$ & $3(25.0 \%)$ & $2(16.7 \%)$ & $1(8.3 \%)$ & $0(0 \%)$ & $12(100 \%)$ \\
Total & 21 & 21 & 30 & 11 & 3 & 86 \\
\hline
\end{tabular}

M, monoclonal pattern (single band); O (2), oligoclonal, two bands; O (>2), oligoclonal, more than two bands; P, polyclonal pattern (smear); N, no PCR products. 


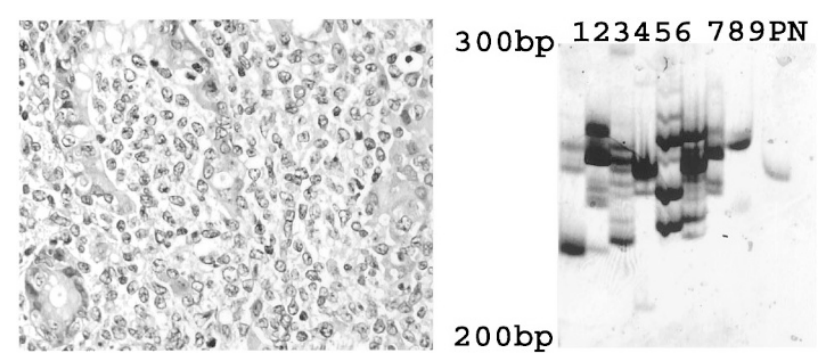

FIGURE 1. A case of combined centrocyte-like cell (CCL) and largecell histologic type with eight lesions (Case 12; hematoxylin and eosin staining, original magnification, $400 \times$ ). Lanes 1 to 8 , samples collected from each lesion; Lane 9, a sample collected from the same lesion as Lane 8. P, positive control; N, negative control. Lanes 1 to 7 show an oligoclonal pattern; Lane 8, a monoclonal pattern; and Lane 9, no PCR products. There are no common bands.

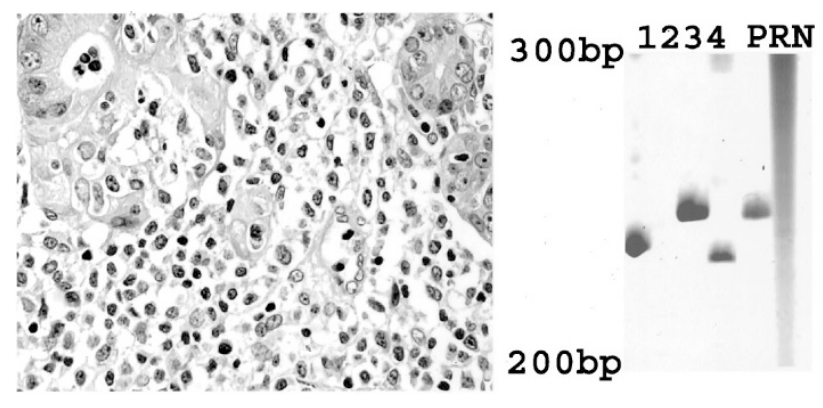

FIGURE 2. A case of combined CCL and large-cell histologic type with two lesions (Case 10); one is a large lesion of CCL histologic type, and another is a small lesion of combined CCL and large-cell type (hematoxylin and eosin, staining, original magnification, $400 \times$ ). Lanes 1, 3, and 4, samples collected from the large CCL lesion, all showing monoclonal pattern but no common bands. Lane 2, a sample from combined CCL and large-cell type showing a smear. P, positive control; $\mathrm{R}$, chronic tonsillitis; $\mathrm{N}$, negative control.

cells showed fewer bands than did those with other histologic types (Table 2), and 75\% of cases with large-cell type had monoclonal or biclonal proliferation.

Presence of common bands between the lesions meant the appearance of common clone of cells (Table 1). All of the common bands in each case showed identical sequences, confirming the same clone of origin. Sequencing data in several cases are shown in Table 3. One common band appeared in every sample in four cases (Cases 1, 16, 17, 18). In Case 1, one common band was found among two samples with CCL histologic type. This case had a small lymphomatous lesion, from which two samples were obtained. One case with a bulky tumor of combined histologic type (Case 16) showed one common band among three samples obtained from separate areas of the lesion (Fig. 3, Table 3). In two cases of large-cell histologic type (Cases 17, 18), three and four samples, respectively, obtained from a single large lesion had a common band (Fig. 4, Table 3). Common band(s) were found in a part of samples in another seven cases (Cases 2, 5, 7 to 9, 12, and 14). Case 2 showed one common band among two samples and another common band among another two samples. Case 5 showed one common band among four of six samples. Case 7 showed one common band among three of five samples. Cases 8, 9, 12, and 14 showed one common band among two of four, three, nine, and four samples, respectively (Fig. 1, Table 3). Remaining seven cases showed no common bands (Fig. 2, Table 3).

\section{DISCUSSION}

The present PCR-based analysis revealed that oligoclonal pattern of growth was common in lesions of gastric MALT lymphoma. These multiple bands seem not to be a PCR artifact because positivecontrol samples always showed a single band and negative-control samples, no products. In addition, the heteroduplex analysis of PCR products prevent forming false-positive band(s), thus enabling easy distinction of clonal band(s) from polyclonal smears $(19,20)$. Furthermore, we ascertained that the dominant bands after heteroduplex formation were made of a single clone by direct sequencing. These findings indicated that the oligoclonal bands were not nonspecific "false-positive" bands.

Wan et al. (22) described the appearance of "nonspecific bands" in PCR-based analysis of immunoglobulin heavy-chain gene rearrangement. They found that samples with a low DNA content or samples with highly diluted B-cell clones might produce one or several bands after electrophoresis on agarose gels. They also reported that the number of nonspecific bands increased with increasing PCR cycles. In this study, all of the samples were ob-

TABLE 3. Nucleotide Sequences of Variable Lesion in Immunoglobulin Heavy-Chain Gene

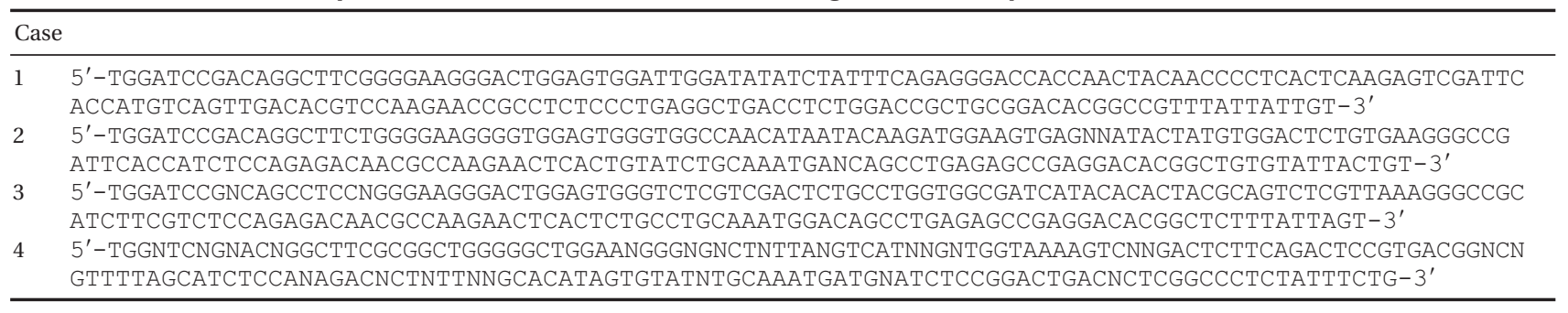

5' end represents Fr2 region, and 3' end represents Fr3 region. 


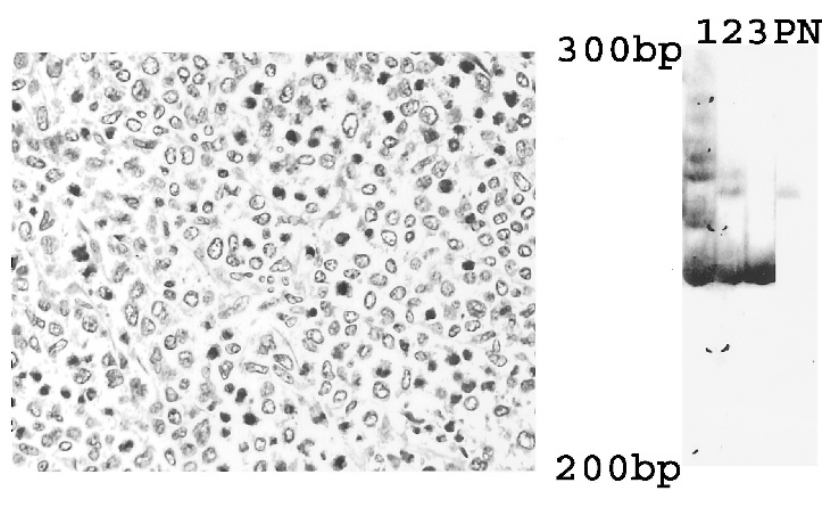

FIGURE 3. A case of a bulky tumor with combined CCL and largecell histologic type (Case 16; hematoxylin \& eosin staining, original magnification, $400 \times$ ). Lane 1, a sample with CCL histologic type; lane 3, a sample with large-cell type. One common band is present among lanes 1 to 3. P, positive control; N, negative control.

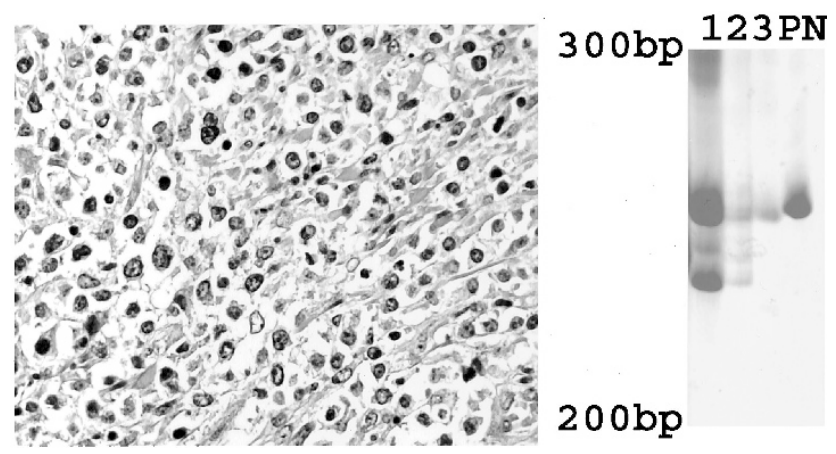

FIGURE 4. A case of a bulky tumor with large-cell histologic type (Case 7; hematoxylin and eosin staining, original magnification $400 \times$ ). Lanes 1 to 3 are samples collected from the separate areas in the lymphomatous lesion. A common band is present among lanes $\mathbf{1}$ to 3 . $\mathrm{P}$, positive control; N, negative control.

tained from the resected specimens containing enough amounts of lymphomatous components for analysis. PCR cycles were optimized through several experiments using proper positive and negative controls. Taken together, appearance of 'nonspecific bands' could be completely avoided in this study.

Thirty-five percent of the gastric lesions were oligoclonal, and monoclonal or biclonal cell proliferation was found in approximately one half of the lesions. Torlakovic et al. (23) reported an indefinite pattern of oligoclonal bands in MALT lymphoma and explained these findings to be caused by a selective proliferation of relatively small number of B-cell clones responsive to $H$. pylori. With respect to histology, $75 \%$ of the present lesions with largecell type showed monoclonal or biclonal pattern proliferation, indicating the advanced stage of MALT lymphoma.

In $11(61 \%)$ of 18 present cases, common clones were found among several lesions of the same cases. Especially in four cases, including two cases with large-cell type, every lesion in the same case contained common clones. The remaining 7 cases showed an oligoclonal proliferation of different clones from lesions to lesions. There have been a limited number of studies similar to ours. Matolcsy et al. (24) reported the different clonal origin of multifocal lesions in one case of gastric MALT lymphoma. These findings suggested that gastric MALT lymphoma started as multiclonal or oligoclonal proliferation of cells, in which separate lesions composed of different clones from each other. As disease advances, dominant clones appear in some lesion and disseminate to other lesions via the homing properties of the proliferating B lymphocytes $(5,6)$.

The mechanism for multiple clonal beginning of gastric MALT-type lymphoma is unknown. One possible explanation is that some genetic changes occur in patients' stomachs, which predispose those patients to proliferation of multiple clones (24). Chronic gastritis caused by $H$. pylori infection is regarded as a prelymphomatous state $(2,3,25)$, in which persistent inflammation might generate genetic alterations in multiple B-cell clones. The recent report of Peng et al. (26) supports this idea by showing occurrence of replication error phenotype, as revealed by microsatellite instability in chronic gastritis lesions before the histological appearance of MALT lymphoma.

\section{REFERENCES}

1. Isaacson P, Wright DH. Extranodal malignant lymphoma arising from mucosa-associated lymphoid tissue. Cancer 1984;53:2515-24.

2. Zucca E, Roggero E, Pileri S. B-cell lymphoma of MALT type: a review with special emphasis on diagnostic and management problems of low-grade gastric tumors. Br J Haematol 1998;100:3-14.

3. Wotherspoon AC, Ortiz-Hildago C, Falzon MR, Isaacson PG. Helicobacter pylori-associated gastritis and primary B-cell gastric lymphoma. Lancet 1991;338:1175-6.

4. Wotherspoon AC, Doglioni C, Isaacson PG. Low-grade gastric B-cell lymphoma of mucosa-associated lymphoid tissue (MALT): a multifocal disease. Histopathology 1992;20:29-34.

5. Isaacson PG, Spencer J. The biology of low-grade MALT lymphoma. J Clin Pathol 1995;48:395-7.

6. Drillenburg P, Van der Voort R, Koopman G, Dragosics B, Van Krieken JHJM, Kluin P, et al. Preferential expression of the mucosal homing receptor integrin $\alpha 4 \beta 7$ in gastrointestinal non-Hodgkin's lymphomas. Am J Pathol 1997;150:91927.

7. Du NQ, Xu CF, Diss TC, Peng HZ, Wotherspoon AC, Isaacson $\mathrm{PG}$, et al. Intestinal dissemination of gastric mucosaassociated lymphoid tissue lymphoma. Blood 1996;88:444551.

8. McCormick C, Philp E, Mansi J, Livni N, McCarthy K. Clonal analysis of three morphologically distinct lymphomas occurring in the same patient. J Clin Pathol 1994;47:1038-42.

9. Neoplasia. In: Cotran RS, Kumar V, Collins T, editors. Robbins pathologic basis of disease. 6th ed. Philadelphia: Saunders; 1999. p. 260-327.

10. Cossman J, Uppenkamp M, Sundeen J, Coupland R, Raffeld M. Molecular genetics and the diagnosis of lymphoma. Arch Pathol Lab Med 1998;112:117-27. 
11. Griesser H. Applied molecular genetics in the diagnosis of malignant non-Hodgkin's lymphoma. Diagn Mol Pathol 1993;2:177-91.

12. Trainor KJ, Brisco MJ, Story CJ, Morley AA. Monoclonality in B-lymphoproliferative disorders detected at the DNA level. Blood 1990;75:2220-2.

13. Wan JH, Trainor KJ, Brisco MJ, Morley AA. Monoclonality in B cell lymphoma detected in paraffin wax embedded sections using the polymerase chain reaction. J Clin Pathol 1990;43:888-90.

14. Ramasamy I, Brisco M, Morley A. Improved PCR method for detecting monoclonal immunoglobulin heavy chain rearrangement in B cell neoplasms. J Clin Pathol 1992;45:770-5.

15. Achille A, Scarpa A, Montresor M, Scardoni M, Zamboni G, Chilosi M, et al. Routine application of polymerase chain reaction in the diagnosis of monoclonality of B-cell lymphoid proliferations. Diagn Mol Pathol 1995;4:14-24.

16. Theriault C, Galoin S, Valmary S, Selves J, Lamant L, Roda D, et al. PCR analysis of immunoglobulin heavy chain $(\mathrm{IgH})$ and TCR- $\gamma$ chain gene rearragements in the diagnosis of lymphoproliferative disorders: results of a study of 525 cases. Mod Pathol 2000;13:1269-79.

17. Greer CE, Wheeler CM, Manos MM. PCR amplification from paraffin-embedded tissues: sample preparation and the effects of fixation. In: Dieffenbach CW, Dveksler GS, editors. PCR primer. New York: Cold Spring Harbor Laboratory Press; 1995. p. 99-112.

18. Diaz-Cano SJ, Brady SP. DNA extraction from formalin-fixed, paraffin-embedded tissues: protein digestion as a limiting step for retrieval of high-quality DNA. Diagn Mol Pathol 1997;6:342-6.

19. Langerak AW, Szczepanski T, Van der Burg, Wolvers-Tettero ILM, Van Dongen JJM. Heteroduplex PCR analysis of rear- ranged $\mathrm{T}$ cell receptor genes for clonality assessment in suspect T cell proliferations. Leukemia 1997;11:2192-9.

20. Gonzalez M, Gonzalez D, Lopez-Perez R, Garcia-Sanz R, Chillon MC, Balanzategui A, et al. Heteroduplex analysis of VDJ amplified segments from rearranged IgH genes for clonality assessments in B-cell non-Hodgkin's lymphoma. A comparison between different strategies. Hematologica 1999;84:779-84.

21. Tuma RS, Beaudet MP, Jin X, Jones LJ, Cheung CY, Yue S, et al. Characterization of SYBR Gold nucleic acid gel stain: a dye optimized for use with 300-nm ultraviolet transilluminators. Anal Biochem 1999;268:278-88.

22. Wan JH, Sykes PJ, Orell SR, Morley AA. Rapid method for detecting monoclonality in B cell lymphoma in lymph node aspirates using the polymerase chain reaction. J Clin Pathol 1992;45:420-3.

23. Torlakovic E, Cherwitz DL, Jessurun J, Scholes J, McGlennen R. B-cell gene rearrangement in benign and malignant lymphoid proliferations of mucosa-associated lymphoid tissue and lymph nodes. Hum Pathol 1997;28:166-73.

24. Matolcsy A, Nagy M, Kisfaludy N, Kelenyi G. Distinct clonal origin of low-grade MALT-type and high-grade lesions of a multifocal gastric lymphoma. Histopathology 1999;34:6-8.

25. Aozasa K, Ueda T, Kurata A, Kim CW, Inoue M, Matsuura N, et al. Prognostic value of histologic and clinical factors in 56 patients with gastrointestinal lymphomas. Cancer 1988;61: 309-15.

26. Peng H, Chen G, Du M, Singh N, Isaacson PG, Pan L. Replication error phenotype and p53 gene mutation in lymphomas of mucosa-associated lymphoid tissue. Am J Pathol 1996;148:643-8. 